\title{
A FALÁCIA DA DEMOCRACIA OU QUANDO A MAIORIA É APENAS UMA MINORIA
}

\author{
THE FALLACY OF DEMOCRACY OR WHEN THE MAJORITY IS ONLY A MINORITY
}

\author{
Recebido em 27.10.2012. Aprovado em 18.03.2013 \\ Avaliado pelo sistema double blind review \\ DOI: http://dx.doi.org/10.12712/rpca.v7i1.217
}

\begin{abstract}
Ivan Antônio Pinheiro
iapinheiro@ea.ufrgs.br

Escola de Administração da Universidade Federal do Rio Grande do Sul (EA/UFRGS) - Porto Alegre - RS, Brasil.
\end{abstract}

\section{Guilherme Moreira Conte}

guilherme.conte@hotmail.com

Escola de Administração da Universidade Federal do Rio Grande do Sul (EA/UFRGS) - Porto Alegre - RS, Brasil.

\section{Luciano José Martins Vieira}

ljmvieira@yahoo.com.br

Escola de Administração da Universidade Federal do Rio Grande do Sul (EA/UFRGS) - Porto Alegre - RS, Brasil.

\section{Paulo Cesar Delayti Motta}

delayti@hotmail.com

Escola de Administração da Universidade Federal do Rio Grande do Sul (EA/UFRGS) - Porto Alegre - RS, Brasil.

\section{Resumo}

A tese deste ensaio é a de que a "nova democracia" pouco guarda de semelhança com a que lhe deu origem, a democracia dos antigos, mas que, não obstante, ainda hoje bastante presente no imaginário e nas expectativas dos cidadãos, até porque, estimulada pelos agentes políticos. Para a sua demonstração os autores reuniram diversas premissas que sustentam o argumento. Por trás desse distanciamento os autores identificam riscos às instituições do sistema democrático, para os quais alertam. Mas se alguns motivos desse distanciamento podem ser atribuídos, por imposição, à própria evolução das sociedades e dos Estados, outros, por certo resultam de opções políticas que podem ser revistas, buscando, assim, novos modelos participativos que não sejam tão divorciados do ideário ainda explorado, mas antes, mais aderentes, eliminando, assim, os riscos futuros. Um exemplo flagrante desse distanciamento é a manipulação pelo Congresso Nacional da noção de maioria, pois parece claro e fora de dúvida que o conceito de maioria simples (relativa) - ainda que legal - não condiz com o sentido historicamente associado à participação democrática, esta mais próxima da noção de maioria absoluta e, mais ainda, da maioria qualificada.

Palavras-chave: Democracia. Maioria. Minoria. Representação.

\begin{abstract}
The main point of this essay is that the "new democracy" has very little to do vis-à-vis the one from which it originated, the ancients democracy, but that, nonetheless, is still strongly present in the citizens imaginings and expectations, even so because stimulated by political agents. To prove this issue the authors identify some risks to the democratic system institutions which they put under the spot. But, if some of the reasons for this detachment may be attributed, by imposition, to the very processes of societies and States evolution, others, for sure, result from political actions which may be revised, thus reaching for new participatory models that are not so much divorced from the ideology yet explored, but, nevertheless, more adherent, thus eliminating future risks. An example of this flagrant detachment is the manipulation by the Congress of the notion of majority, because it seems clear and out of question that the concept of simple majority (relative) - although legal - is nearer to the
\end{abstract}


notion of absolute majority and, even more, of the qualified majority.

Keywords: Democracy. Majority. Minority. Representantion.

\section{Introdução}

Democracia: palavra mágica repleta de significados, capaz de despertar os mais nobres (e outros nem tanto) sentimentos, bem como provocar atitudes impensadas. Como verdadeiro ideal, ou falsa justificativa para interesses escusos, a busca pela democracia ainda é motivo de revoltas e guerras, não faltando exemplos na História dos povos. Nessas lutas são inomináveis os mártires, muitos levados ao limite do sacrifício voluntário por autoimolação, sinal inequívoco da elevação da democracia a valor da e para a humanidade. Ao lado da liberdade e da república como forma de governo, a democracia constitui o tripé que orienta tanto as reflexões no campo da ciência política quanto a análise da práxis governamental e, quando inexistente, reivindicada com todas as forças pelos povos, como recentemente testemunhado nos países da África setentrional e no médio oriente.

De um modo geral, pois sem dúvida registram-se exceções, pode-se afirmar que o século XXI, pelo menos no seu limiar, tem se revelado mais democrático do que os que o antecederam; todavia, ainda não livre de objeções no que tange à natureza desta, provisoriamente, denominada "nova democracia", posto que distinta da concebida pelos antigos, mas também pelos modernos, como será demonstrado.

Destarte, os objetivos deste texto, escrito na forma de ensaio, porém ancorado em pesquisa bibliográfica, são trazer evidências, chamar à reflexão e promover o debate sobre uma preocupante constatação: a de que, em que pese a maioria das realizações políticas levar a chancela de "iniciativa democrática", na prática, seja na origem ou ao longo do processo, esta se perdeu, se não de fato, de direito, quando não ambos, sendo inequívoco que já há muito que a noção do que seja o ideal democrático foi esmaecida, sendo hoje uma sombra do seu passado.

Após breve revisão da literatura acerca da democracia (conceito, evolução histórica, alternativas, considerações críticas, etc.), a opção pela definição de Bobbio (2000a) leva a que, na segunda seção, a discussão orbite em torno do entendimento sobre, afinal, o que é "maioria". Definidos os pilares fundamentais do argumento, a tese que se pretende demonstrar tem início na seção "3 Quando a maioria é ... a minoria" - e se estende pelas seções "4 - Distorções ao princípio da maioria no seio do Poder Legislativo" e "5 - Outras situações nas quais a minoria usurpa o poder da maioria". Como nas seções antecedentes foram tecidas algumas considerações críticas, estas, acrescidas de outras, foram reunidas na sexta e última seção, onde os autores também alertam para os riscos do sistema atual, bem como para iniciativas que, se não solucionam, contribuem para mitigar o quadro identificado. Os exemplos foram extraídos da realidade brasileira contemporânea, foco do estudo; todavia, há evidências de que esta não é uma exceção.

\section{Democracia}

Não há como discutir democracia sem recuar tão longe quanto se queira no tempo histórico; todavia, a referência clássica é a civilização grega, mas também se poderia recorrer à república romana, onde também ela floresceu. De outro lado, não há como falar em democracia sem associála à participação, à cidadania, à liberdade e à igualdade, entre outros construtos sociais. No que tange à igualdade, Nay (2007) resgata o entendimento dos gregos, para os quais uma só expressão isotês - traduzia os ideais de igualdade e equidade, estes, por todos defendidos como devendo ser os pilares morais da sociedade. Todavia, enquanto um grupo representado pelos interesses aristocráticos defendia a igualdade entre os pares (a eunomia), mantendo, assim, a desigualdade relativa na sociedade, outros defendiam o oposto, a igualdade absoluta, a isonomia entre os integrantes, tendo-se, pois, desde então, estabelecido um conflito hoje percebido como histórico. 


\section{Ivan Antônio Pinheiro, Guilherme Moreira Conte, Luciano José Martins Vieira e Paulo Cesar Delayti Motta}

Se a controvérsia é antiga, a prática do sentido atribuído à igualdade, ora como eunomia, ora como isonomia, não é menos, prevalecendo até hoje. A primeira é a igualdade inter pares, que distingue, por exemplo, as corporações (de representação, de profissionais, etc.) dos demais grupos, assim como estas entre si, enquanto a segunda é a igualdade democrática, mais proximamente traduzida na expressão: "cada cabeça, um voto". Todavia, ambos os conceitos são estreitamente vinculados à democracia; por exemplo, alinhados com a primeira noção temos S. Mill, mas também Platão, em que pese ambos apresentarem muitas divergências.

Contudo, ainda que haja controvérsias, parece não haver dúvidas de que o sentido da expressão "avanço democrático" se encontra mais próximo da ideia de isonomia do que da de eunomia. Assim, associada a ela, não raro tem-se o registro da contínua ampliação do conjunto de participantes na vida política, tendo sido conferidos, entre outros, o direito ao voto aos destituídos de bens (com a eliminação do sufrágio censitário), aos jovens, às mulheres, aos apenados e, em alguns países, o direito se estende até aos residentes no exterior. Seria, pois, uma surpresa encontrar uma redução no conjunto de participantes à frente do processo decisório em ambiente democrático.

Nessa questão de igualdade e democracia é ainda Nay (2007, p. 29-30) quem chama a atenção para o fato de que

[...] a maioria dos filósofos e reformadores atenienses persistem em defender uma concepção restritiva da igualdade; a igualdade só vale para aqueles que podem de fato ser reconhecidos como; por isso não poderia ser aplicada a seres de valor desigual [...] Assim, a democracia não surge a partir de um igualitarismo abstrato, que recusa toda distinção entre os cidadãos [...] descansa na busca de um equilíbrio que visa, na organização concreta da cidade, à conciliação de duas visões de igualdade.

A título de curiosidade, no limite, contrario sensu, ao governo de todos não cabe denominar de democracia, mas mais apropriadamente, de onicracia; todavia, a denominação democracia tornou-se a referência para traduzir a ideia de participação crescente e deliberação majoritária. Contudo, senão por outros motivos de ordem política, por limitação física e de tempo, a democracia comporta qualificação restritiva, cabendo lembrar a crítica e a ressalva sempre levantadas à democracia ateniense que excluía, entre outros, os escravos. Péricles, sempre lembrado como grande estadista e um dos pais da democracia ateniense, por exemplo, restringiu o conceito de "cidadão ateniense", passando a exigir como condição para o exercício pleno da cidadania que pai e mãe fossem atenienses, o que implicou a redução do conjunto de potenciais atores no cenário e nas atividades democráticas. Ao discutir as questões relativas ao governo e à democracia, Locke $(1978$, p. 85) já sinalizava essas dificuldades:

Tendo a maioria, conforme mostramos, quando de início os homens se reúnem em sociedade, todo o poder da comunidade naturalmente em si, pode empregá-lo para fazer leis destinadas à comunidade de tempos em tempos, que se executam por meio de funcionário que ela própria nomeia: nesse caso, a forma de governo é uma perfeita democracia; ou então pode colocar o poder de fazer leis nas mãos de alguns homens escolhidos, seus herdeiros e sucessores: nesse caso, ter-se-á uma oligarquia [...].

Mutatis mutandis, embora quase quatro séculos separem dos dias de hoje a afirmativa acima, sendo natural, portanto, a existência de algumas diferenças, a exemplo da convocação eventual e da duração variável do funcionamento do parlamento, ainda assim a expressão democracia não perdeu o sentido de participação ativa da comunidade, tal como afirmavam os antigos.

Mais contemporâneo, Bobbio (2000a, p. 30) atualiza o conceito afirmando que

[...] o único modo de se chegar a um acordo quando se fala de democracia, entendida como contraposta a todas as formas de governo autocrático, é o de considerá-la caracterizada por um conjunto de regras (primárias ou fundamentais) que estabelecem quem está autorizado a tomar as 
decisões coletivas e com quais procedimentos.

Todavia, mais adiante ele mantém o sentido de participação majoritária, pois:

\begin{abstract}
No que diz respeito aos sujeitos chamados a tomar (ou a colaborar para a tomada de) decisões coletivas, um regime democrático caracteriza-se por atribuir este poder (que estando autorizado pela lei fundamental torna-se direito) a um número muito elevado de membros do grupo [...] a regra fundamental da democracia é a regra da maioria, ou seja, a regra à base da qual são consideradas decisões coletivas - e, portanto, vinculatórias para todo o grupo - as decisões aprovadas ao menos pela maioria daqueles a quem compete tomar a decisão. (BOBBIO, 2000a, p. 31).
\end{abstract}

O senso de participação atomizada está também presente na discussão de Bobbio (2004, p. 77) sobre os direitos, uma vez que "O individualismo é a base filosófica da democracia: uma cabeça, um voto". Nesse sentido, vale notar que entre as principais conquistas dos revolucionários franceses (1789) estão a extinção do voto por classe substituído pelo voto por cabeça e a eliminação da vinculação, tornando o voto, assim, livre. Não tivesse sido assim "O Terceiro [Estado], que elegera mais deputados (578) do que a nobreza e o clero juntos (561), sempre perderia por dois a um" (OSTERMANN; KUNZE, 1995, p. 36) e nenhuma mudança revolucionária teria acontecido. Cabe lembrar, ainda, que o Terceiro Estado contou (dada a queda da vinculação) com votos de parte da nobreza liberal e também do baixo clero (BLUCHE; RIALS; TULARD, 1989). Portanto, para Locke e Bobbio, assim como, praticamente sem erro se pode afirmar, independentemente de outros autores que eventualmente se venha a consultar, é fora de dúvida que para uma decisão, governamental ou não, ter legitimidade democrática, deve contar com a participação e a aprovação da maioria efetiva dos integrantes da comunidade ou do grupo de referência.

Se, no início dos tempos era fácil reunir os interessados (em uma praça - a ágora) e deliberar sobre determinados assuntos, em geral relacionados à guerra ou aos impostos, hoje isto se revela impossível. Restam da experiência dos tempos antigos as expressões "democracia direta", "democracia participativa", assim como "democracia dos antigos", utilizadas indistintamente por autores diversos. Nas constituições contemporâneas, a exemplo da brasileira, os estatutos do plebiscito, do referendo e da iniciativa popular (PRADO, 1994) são os que mais se aproximam da democracia direta. A essas outras iniciativas podem ser acrescidas, como as consultas e audiências públicas e a participação deliberativa em colegiados (Conselhos e Comissões que atuam junto ao poder público), ainda que estas encerrem, de regra, representação institucional ou classista.

Nas palavras de Bobbio (2000a, p. 63), "para que exista democracia direta no sentido próprio da palavra, isto é, no sentido em que direto quer dizer que o indivíduo participa ele mesmo nas deliberações que lhe dizem respeito, é preciso que entre os indivíduos deliberantes e a deliberação que lhes diz respeito não exista nenhum intermediário". Assim, o cidadão, direta e normalmente de forma presencial, exerce o seu direito à voz nas decisões julgadas importantes. Sem intermediários, o cidadão pode ir ao centro da deliberação e expressar sua vontade para que esta seja computada no processo decisório. Sem intervenções entre a sua vontade e a manifestação da mesma, o votante é capaz de trazer suas ideias em essência, de modo que nada do que seja dito por ele esteja em desconformidade com sua vontade.

Todavia, as imposições da vida nos complexos urbanos, com suas múltiplas demandas (pessoais, familiares e profissionais) sobre um tempo limitado e escasso, levaram à consagração da democracia representativa. De acordo com Bobbio (2000a, p. 56), "A expressão democracia representativa significa genericamente que as deliberações coletivas, isto é, as deliberações que dizem respeito à coletividade inteira, são tomadas não diretamente por aqueles que dela fazem parte, mas por pessoas eleitas para esta finalidade". O cidadão elege alguém que considera capaz de representar suas vontades para levá-las ao centro das decisões e opinar em seu nome. Assim, o direito à voz é exercido por representação. No plano ideal o representante seria capaz de expressar e 


\section{Ivan Antônio Pinheiro, Guilherme Moreira Conte, Luciano José Martins Vieira e Paulo Cesar Delayti Motta}

representar a vontade do seu eleitorado, mas é Bobbio (2000a, p. 38) quem também adverte: “A democracia representativa [...] é já por si mesma uma renúncia ao princípio da liberdade como autonomia".

Direta ou representativa (também denominada indireta), historicamente a democracia tem enfrentado críticas e restrições. As dificuldades, as limitações, os riscos e as desvantagens da democracia enquanto forma de governo são de amplo conhecimento como bem ilustrado por Bobbio (2000a), quando cita a História, de Heródoto, de onde extrai o que denomina de "Uma Célebre Discussão" entre três persas - Otanes, Megabises e Dario - sobre a melhor forma de governo a adotar no seu país. Otanes defende a democracia afirmando que

O governo do povo, porém, merece o mais belo dos nomes, isonomia; não faz nada do caracteriza o comportamento do monarca. Os cargos públicos são distribuídos pela sorte; os magistrados precisam prestar contas do exercício do poder; todas as decisões estão sujeitas ao voto popular. Proponho, portanto, rejeitarmos a monarquia, elevando o povo ao poder: o grande número faz com que tudo seja possível. (BOBBIO, 2000a, p. 40).

Sucede aos demais interlocutores a defesa da monarquia e da aristocracia como a melhor dentre as formas de governo; todavia, elaboradas a partir de críticas às limitações das demais, tal como Otanes quando da sua defesa da democracia atacou a monarquia. Há, pois, uma circularidade e regressão infinita. Por evidência empírica constata-se que cada forma não reúne apenas virtudes, mas antes, cada uma se afirma por sobre as desvantagens das demais. Assim, a discussão termina inconclusa; mas, para os propósitos deste ensaio é suficiente registrar que, desde a antiguidade, a democracia é, apesar das vantagens reconhecidas, também vista com reservas.

Desde A República, Platão (2000, p. 273) mostra que pelas suas origens a democracia não é uma das formas veneráveis de governo; ao contrário, ela "“...] surge quando os pobres, tendo vencido os ricos, eliminam uns, expulsam outros e dividem por igual com os que ficam o governo e os cargos públicos". Também os elementos que descrevem o sistema, os governantes e os habitantes que melhor se ajustam à democracia como forma de governo confirmam esse posicionamento: “[...] um governo agradável, anárquico e variado, que dispensa uma espécie de igualdade, tanto ao que é desigual como ao que é igual" (PLATÃO, 2000, p. 275). O fato de a democracia ateniense se basear na escolha por sorteio foi objeto de críticas, pois, no entendimento de Platão, a escolha dos magistrados, ou seja, daqueles que ocupariam os cargos públicos, deveria ser pautada não na sorte, mas antes na competência e na experiência, e nem todos reuniriam as condições necessárias; pensamento que ainda hoje acompanha vários estudiosos.

Aristóteles também não era seu admirador, pois afirma que

[...] A democracia é a menos má das três espécies de perversão, pois no seu caso a forma de constituição apresenta apenas um ligeiro desvio [...] é encontrada sobretudo nas famílias sem um chefe (todos se encontram em um nível de igualdade), e naquelas em que o chefe é fraco e todos agem como bem entendem. (ARISTÓTELES, 2007, p. 186-7).

A crítica motivada pela efetiva descrença de Rousseau na democracia representativa é bastante conhecida. Efetivamente, para Rousseau (2000, V. I, p. 186-7),

A soberania não pode ser representada pela mesma razão por que não pode ser alienada, consiste essencialmente na vontade geral e a vontade absolutamente não se representa. É ela mesma ou é outra, não há meio-termo. Os deputados do povo não são, nem podem ser seus representantes; não passam de comissários seus, nada podendo concluir definitivamente. É nula toda lei que o povo diretamente não ratificar; em absoluto, não é lei. O povo inglês pensa ser livre e muito se engana, pois só o é durante a eleição dos membros do parlamento; uma vez estes eleitos, ele é escravo, não é nada. 
Segundo Rousseau (2000) a democracia jamais existiu verdadeiramente; para que isso ocorresse algumas condições deveriam ser atendidas: 1) um Estado geograficamente pequeno, para que todos pudessem se reunir e expressar, de voz própria, suas vontades; 2) uma simplicidade que impedisse a existência de problemas maiores e que pudessem opor os grupos em discussões espinhosas; e, por último, 3) igualdade de condições e fortunas, de modo que nenhum fosse distinto em função das suas posses. Percebe-se que Rousseau acreditava firmemente que, apesar de a democracia direta se mostrar a melhor forma de atender os anseios da sociedade, só era possível no plano ideal.

Em que pese considerá-la a melhor forma de governo, S. Mill também aponta as falhas da democracia representativa, entre elas, a do voto não qualificado, razão pela qual revela preferência pela eunomia, devendo os governantes ser eleitos a partir de um conjunto restrito de candidatos detentores de conhecimentos; algo que lembra o Conselho dos idosos (na Grécia antiga) bem como guarda semelhança com as propostas de Platão. Em análise dos sistemas de votação, em $O$ Governo Representativo, Mill (2006) sugere a adoção do Sistema Hare como forma de corrigir a deficiência da representação (proporcional) das minorias no parlamento. Mais especificamente, o autor alude ao Tratado sobre eleição de representantes, parlamentar e municipal, publicado pelo jurista Thomas Hare em 1859 e que identifica como "[...] dentre os maiores avanços já realizados na teoria e prática de governo" (MILL, 2006, p. 119). Atualmente, o que mais se aproxima do Sistema Hare é o chamado Sistema de Voto Único Transferível, conhecido pela sigla STV, utilizado na Irlanda, desde 1921, para as eleições da Câmara Baixa (NICOLAU, 1999).

Por fim, embora a democracia tenha sido a forma de governo dominante nos mais famosos sistemas utópicos - A República (PLATÃO, 2000), A Utopia (MORUS, s.d.) e A Cidade do Sol (CAMPANELLA, 2004) -, por força da História, hoje, se ela não é a ideal, é o alvo, não sem a ressalva de W. Churchill (2011, p.1): "Ninguém pretende que a democracia seja perfeita ou sem defeito. Tem-se dito que a democracia é a pior forma de governo, salvo todas as demais formas que têm sido experimentadas de tempos em tempos". Mais de dois milênios de experiência política, mais notadamente a partir da Era Moderna, justificam as críticas que hoje se faz à democracia, pois, conforme disse Bobbio (2000a), mais do que diferenças, há "contrastes entre o que foi prometido e o que foi realizado".

Portanto, desde idos tempos se tem conhecimento das falhas e das limitações da democracia, como, entre outras: a tendência à demagogia, o risco de permanente assembleísmo devido à impossibilidade de conciliar conflitos insuperáveis, o voto não qualificado, isto é, independentemente do lastro patrimonial, assim como de conhecimento (escolaridade) dos cidadãos-eleitores, morosidade e eventual desvirtuamento de propósito ao longo do processo decisório. Todavia, nunca, pelo que se pode observar, a expressão democracia perdeu o sentido de decisão a partir de um coletivo (que historicamente tem crescido) e que se manifesta de forma majoritária, quer direta ou indiretamente. Pelo menos, é isto o que se espera.

Nesse sentido, Bobbio (1988) salienta que no regime democrático a maioria tende a se estruturar e a constituir uma hierarquia imutável; a maioria pode se consolidar e afogar a minoria. É o que o autor chama de "tirania da maioria" (merecedora de um capítulo na obra citada). Assim, progressivamente, a maioria sobrepor-se-á à minoria, que terá sua voz reduzida até deixar de existir. Dessa forma, as suas vontades jamais serão atendidas, de maneira que a maioria consolidar-se-á e alcançará um estágio de organização que somente as suas vontades serão consideradas nos momentos de deliberação; no limite se aproximaria do que Kant (2010, p. 28) observou:

Entre as três formas de Estado, a democracia, no sentido próprio da palavra, é necessariamente um despotismo, porque ela funda um poder executivo onde todos decidem sobre e, no caso extremo, também contra um (aquele que, portanto, não consente), por conseguinte todos que não são, contudo, todos, o que é uma contradição da vontade geral consigo mesma e com a liberdade. 


\section{Ivan Antônio Pinheiro, Guilherme Moreira Conte, Luciano José Martins Vieira e Paulo Cesar Delayti Motta}

O receio dos desdobramentos da tirania da maioria pode ser visto no texto em que Bobbio (1988, p. 55) comenta a posição de Tocqueville e Mill: "A ameaça que deriva da democracia como forma de governo é para ele [A. de Tocqueville], como de resto para o amigo J. S. Mill, a tirania da maioria: o perigo que a democracia corre como progressiva realização do ideal igualitário é o nivelamento, cujo efeito final é o despotismo.”. A propósito, Mill (2006) também dedica um capítulo ao tema da tirania, o VII - Da verdadeira e falsa democracia; representação de todos ou apenas da maioria, no já citado $O$ Governo Representativo.

Foi o risco à ditadura da maioria que levou ao surgimento e à consagração em muitas Constituições, a exemplo da Alemã e da Portuguesa, do chamado direito de minoria. É Paulo Brossard (2004, p. 19), ex-senador e ministro aposentado do Supremo Tribunal Federal, quem esclarece:

Se bem me lembro, foi a Constituição alemã de 1919, elaborada logo depois da I Grande Guerra [...] a primeira a cuidar da CPI, como auxiliar inerente às atribuições parlamentares. Foi a Constituição de Weimar, porém, que assegurou à minoria a prerrogativa de criá-las. Querendo ou não a maioria, basta um terço de cada casa para que CPI seja criada na forma da lei. É um caso de deliberação minoritária.

Posteriormente, tendo voltado ao assunto, acresceu: "Foi consagrada [a prerrogativa da minoria] pela Constituição de Weimar, em 1919, donde a recolheu a nossa Constituição de 1934 [...] nunca mais a regra deixou de ser observada". (BROSSARD, 2005, p. 15). Por fim, ainda sobre o direito das minorias, Santi (2007, p. 106), ao comentar o posicionamento do Ministro Celso de Mello em pedido de liminar de Mandado de Segurança, assevera que

[...] reconhecimento, em nosso sistema político-jurídico, da existência de um verdadeiro estatuto constitucional das minorias parlamentares [...] direitos políticos que considera básicos de uma república democrática: direito de oposição, direito de minorias, que não podem ser oprimidas pela maioria, e a possibilidade real de alternância de poder.

Portanto, no sistema democrático a regra é a maioria, cabendo à decisão da minoria apenas os casos justificadamente previstos para o exercício do necessário controle e da fiscalização sobre a maioria. Ademais, conforme demonstrado, as atenções, ou melhor, as preocupações, sempre estiveram voltadas à possibilidade de uma ditadura da maioria, e não o inverso. Demonstrar que o não esperado vem ocorrendo, seria, pois, uma surpresa cuja consequência sobre o funcionamento das demais instituições do Estado democrático e de direito merece ser tempestivamente avaliada. Mas se a ditadura da maioria é nociva, o quê dizer, então, da ditadura da minoria, sobretudo quanto esta se apresenta revestida como maioria?

\section{AFINAL, QUAL O SIGNIFICADO DA EXPRESSÃO MAIORIA?}

Para poder quantificar as manifestações de vontade dos que participam de determinado processo decisório, como é o caso, por exemplo, de uma eleição ou da votação de um texto na Casa Legislativa, faz-se necessário reuni-las no centro deliberativo e contá-las conforme o procedimento adotado: cédulas de papel, voto eletrônico, pedras extraídas de um recipiente ou até mesmo pelo simples ato de levantar o braço em sinal de conformidade (há ainda nos Parlamentos, em sinal de praticidade, o habitual: "quem estiver de acordo permaneça como está", em geral seguido do "aprovado por unanimidade"). Para que tal cálculo seja feito, e para que a formação de maioria seja constituída, há três métodos de qualificação: o sistema de maioria simples, o de maioria absoluta, e o de maioria qualificada:

- a maioria simples corresponde à metade mais um, dentre os presentes no processo deliberativo, independentemente de qual seja o total de integrantes do colegiado. Por esse motivo é também denominada de maioria relativa ou ocasional, pois é obtida a partir do número de votantes presentes no momento; assim, não é uma quantidade prefixada. Por 
exemplo, de um conjunto de 15 votantes, se apenas cinco estiverem presentes, bastam três votos para assegurar a maioria simples e aprovar a deliberação em pauta; todavia, se sete estiverem presentes, quatro votos serão necessários. Uma variante da maioria simples impõe a exigência de quórum mínimo (por exemplo, de x\% dos integrantes do colegiado, um representante de cada categoria representada, etc.), por vezes estabelecida para a primeira chamada, sendo que, decorrido o prazo regulamentar, fica livre a deliberação com qualquer quórum;

- a maioria absoluta é constituída pela metade mais um, dentre todos os membros do colegiado. Em casos de coletivo com número ímpar de elementos, arredonda-se para cima, por exemplo, na hipótese de o colegiado possuir 11 integrantes, a maioria absoluta é atingida a partir do sexto voto: já se o total do colegiado for representado por um número par, é possível chegar à maioria absoluta mediante a instituição do chamado voto de Minerva, de desempate, em geral conferido à autoridade que preside a mesa; e, por fim,

- a maioria qualificada, que exige o cumprimento de alguma exigência restritiva com o intuito de conferir maior legitimidade à maioria. Assim, por exemplo, ao contrário da maioria absoluta que requer apenas um voto excedente, na maioria qualificada é imposta uma proporção maior: $2 / 3,3 / 5$, entre outras. Ademais, pode exigir em segundo turno a confirmação da primeira votação.

Finalmente, no caso extremo, a maioria é representada pela unanimidade do colegiado de referência.

Como visto, a expressão "maioria" carrega diferentes significados e a sua obtenção, de regra, é uma disputa em que pesam, ainda, outras regras, a exemplo: 1) a presidência do colegiado pode ou não se manifestar, definindo, assim, a maioria; 2) pode ou não, ter o voto qualificado, chamado de Minerva - o que pode significar o valor em dobro do seu voto; 3 ) os votos declarados nulos ou as abstenções poderão ou não ser computados para a apuração do resultado que definirá a maioria. Há ainda outras variantes cuja adoção resulta da experiência do colegiado em apreço. A condição do voto, se aberto ou secreto, em determinadas situações pode se revelar uma qualificação, como é o caso, hoje, no Brasil, quando se trata de deliberação, entre pares, acerca da perda de mandato parlamentar, havendo diferenças entre os estados membros (em respeito ao princípio federativo). Tullock (2005) apresenta um caso muito interessante, que denomina de "paradoxo da votação", identificado preliminarmente por Condorcet - a habilidade de quem define a agenda, isto é, a ordem de escolha, que é quem geralmente preside a sessão em sistemas de maioria simples, pode induzir o grupo maior à escolha de alternativas que correspondam à preferência de grupos menores, com interesses localizados.

Por certo que a decisão sobre qual "maioria" será aplicada ao caso concreto é uma das mais importantes em um regime democrático e até mesmo o identifica enquanto tal. Portanto, não é uma decisão fácil, posto que multivariada e complexa, pois, entre outras, guarda relação direta com a relevância, o impacto e a possibilidade de reversibilidade da decisão em tela. De indiscutível importância são, ainda, a celeridade do processo e a qualidade do produto final, a exemplo de uma norma, eventualmente, uma lei. Todavia, tanto a qualidade, como a legitimidade do processo, resultam da pluralidade de ideias em debate, requerendo, por conseguinte, ampla participação e maturidade reflexiva, daí as inescapáveis tensões entre a celeridade e a qualidade, ambas exigidas. Grosso modo, as situações de menor importância deverão ser decididas mediante posicionamento da maioria simples; já as de maior relevância serão apreciadas a partir do voto qualificado.

Conforme visto o conceito de "maioria", por definição, admite mais de um entendimento, daí, talvez por isso, o senso comum tenha popularizado a expressão "a grande maioria" quando pretende 


\section{Ivan Antônio Pinheiro, Guilherme Moreira Conte, Luciano José Martins Vieira e Paulo Cesar Delayti Motta}

sinalizar o posicionamento francamente majoritário

Antes de passar à discussão do argumento central deste texto, uma observação não menos importante: parece claro e fora de dúvida que o conceito de maioria simples (relativa) - ainda que legal - não condiz com o sentido historicamente associado à participação democrática, esta mais próxima da noção de maioria absoluta e, mais ainda, da maioria qualificada.

\section{Quando a maioria é ... a minoria}

Ainda que o campo de análise esteja restrito ao setor público, são inúmeras as ocorrências que autorizam questionar até que ponto o emprego da regra da maioria, em razão dos seus diferentes conceitos, de fato (independentemente de ser de direito) corresponde ou não à prática democrática. É preciso delimitar. Assim, a primeira reflexão diz respeito a quando usar este ou aquele conceito de maioria, o que será realizado tendo como ilustração as práticas havidas no curso do processo legislativo para, na sequência, abordar o caso do processo eleitoral.

\section{Frente aos diferentes entendimentos acerca do que seja a maioria, qual e por que motivo escolher um a ser aplicado?}

Denomina-se processo legislativo a atividade precípua do Poder Legislativo de elaborar textos normativos que correspondam à vontade geral da sociedade e, por este motivo, dotados de caráter vinculatório sobre todos aqueles que coabitam o mesmo território. No Brasil, ao nível da União, o processo está definido no Art. 59 da Constituição Federal (BRASIL, 1988) e corresponde a: 1) fazer emendas à Constituição; 2) complementar a Constituição através de Leis Complementares - LC; 3) elaborar Leis Ordinárias - LO - (propriamente ditas, assim como Códigos e Estatutos); 4) Leis Delegadas; 5) apreciar as Medidas Provisórias de iniciativa do Poder Executivo; 6) editar Decretos Legislativos e, 7) elaborar Resoluções. À exceção das Medidas Provisórias (exclusivas da União) e das Leis Delegadas (admitidas em alguns estados da federação) as demais espécies do gênero processo legislativo têm previsão tanto nas Constituições Estaduais quanto nas Leis Orgânicas Municipais.

Ademais, entre as espécies deve ser observada a seguinte hierarquia descendente: LC porque conferem o detalhe e o esclarecimento ausentes do texto constitucional; logo abaixo, as Leis Ordinárias (a título de curiosidade: há divergências entre os doutrinadores se as LO situam-se abaixo ou no mesmo nível das LC), pois, conforme a Constituição Atualizada e as Leis Complementares, estas com elas não podem colidir, mas antes especificar direitos, obrigações, sanções, definir programas, regular, estruturar, entre outros aspectos do relacionamento entre as pessoas físicas e jurídicas, de direito público ou privado. No mesmo nível hierárquico, porém distintas no conteúdo e na forma de encaminhamento, situam-se as Leis Delegadas e as Medidas Provisórias. Os Decretos Legislativos, assim como as Resoluções, normas com finalidade mais específica e de impacto mais restrito, não serão objeto de análise neste texto, muito embora a crítica que encerra também a eles possa ser estendida.

As alterações constitucionais, em razão da insegurança jurídica que a sua mera cogitação pode instalar, não devem ser frequentes, pois poderiam trazer mais prejuízos do que benefícios à sociedade através da paralisia entre os agentes econômicos que, receosos quanto as eventuais mudanças, não se arriscariam em negócios de médio e longo prazo, sem dúvida, os de maior relevância, a exemplo dos investimentos em infraestrutura. Ademais, as propostas, antes de serem convertidas em texto constitucional devem ser amadurecidas na e pela sociedade, o que demanda tempo para o debate à exaustão. De outro lado, do ponto de vista doutrinário, não caberia ao legislador ordinário, em procedimento sumário, modificar os desígnios mais perenes do legislador 
constituinte, sobretudo se este estivesse revestido de poder originário e exclusivo. Destarte, por esses, entre outros motivos, as propostas de Emendas à Constituição devem ser apreciadas e votadas por quórum qualificado. No caso brasileiro, 3/5 dos representantes de cada Casa Legislativa, sendo ainda exigida dupla votação em cada uma. Além desse exemplo, o mais citado, o quórum qualificado, neste caso de $2 / 3$, é exigido para a decretação do impeachment, situação também de indiscutível relevância. É habitual, também, e não apenas no setor público, a exigência do quórum qualificado, por exemplo, de $2 / 3$ dos integrantes para a autoconvocação de órgãos colegiados, evitando, assim, ficar refém daquele que detém a competência para a iniciativa.

À exceção dos casos de maior relevância, a regra geral está estabelecida na Constituição Federal: "Art. 47 - Salvo disposição constitucional em contrário, as deliberações de cada Casa e de suas comissões serão tomadas por maioria de votos, presente a maioria absoluta de seus membros" (BRASIL, 1988). Cabe notar que o dispositivo constitucional se manifesta, simultaneamente, pela adoção dos dois tipos de maioria: a absoluta, para a definição do quórum mínimo, seguida da simples, para a deliberação das matérias.

Assim, em menor grau de qualificação situa-se a maioria absoluta, e por isso exigida para a deliberação e aprovação das propostas de Leis Complementares. Já as Leis Ordinárias podem ser aprovadas mediante maioria simples (esta diferença é, inclusive, um dos argumentos dos que situam a LC em ordem superior à LO). Por fim, o Legislativo para derrubar o veto (total ou parcial) do Poder Executivo também deve reunir a maioria absoluta dos votos.

\section{Um olhar mais atento à aprovação das Leis Ordinárias}

As Leis Ordinárias constituem os casos mais frequentes de apreciação e deliberação nas Casas Legislativas, por isso a necessidade do seu destaque, pois é um dos casos mais claros de contrariedade ao princípio democrático. Supondo, por exemplo, uma Casa Legislativa com 100 assentos votantes e, de acordo com o que foi visto anteriormente, tem-se o sequinte quadro:

- maioria qualificada $=3 / 5=60$ votos (para Emendas à Constituição);

- maioria absoluta $=50 \% \mathrm{~s} / 100+1=51$ votos (para LC e derrubada de veto);

- maioria simples com quórum mínimo (para Leis Ordinárias):

$\circ$ quórum $=50 \%+1=51$ votos; $\mathrm{e}$,

$\circ$ maioria simples $=26$ votos.

Portanto, bastam 26 votos, uma minoria se levado em conta que a Casa possui 100 votantes, para aprovar medidas que não podem ser ditas de somenos relevância, como é o caso das Leis Ordinárias, pois o seu impacto se verifica por sobre todos os cidadãos. Esse quadro, combinado à ausência de parlamentares, por falta de interesse ou qualquer outro motivo, favorece que um pequeno, porém organizado grupo (por vezes com maldisfarçadas intenções) aprove praticamente qualquer matéria, sobretudo as que escapam ao exame mais minucioso por parte da mídia na maioria das vezes atenta a tantos outros acontecimentos. Assim, ainda que minoria, circunstancialmente um grupo se revela como maioria, simples, porém maioria. Tal prática, com certeza, não é do conhecimento do cidadão-eleitor comum e tampouco é esclarecida e discutida pela mídia (o quarto Poder em razão da sua capacidade formadora de opinião) que, quando noticia a aprovação, refere, de regra, ter sido aprovada pela Casa, sugerindo, implicitamente, e sendo este o entendimento do cidadão, que houve, de fato, "o de acordo" da maioria, qual seja, pelo menos, $50 \%$ +1 dos integrantes. Sem dúvida, um engodo.

Embora a questão do quórum tenha sido abordada na perspectiva do número de votos necessário à aprovação, os regimentos dos colegiados, de regra, também estabelecem quórum mínino (por vezes a maioria) para a proposição de matérias, a inversão e prioridade de pauta (casos de urgência e 


\section{Ivan Antônio Pinheiro, Guilherme Moreira Conte, Luciano José Martins Vieira e Paulo Cesar Delayti Motta}

urgência urgentíssima), bem como para a abertura e a continuidade dos trabalhos.

Por oportuno, cabe também esclarecer que, ainda que se afigure absurda a possibilidade criada pela regra da maioria simples (sim, pois ao invés de a maioria aprovar, quem o faz é a minoria), ela - a regra, a possibilidade - é necessária para evitar a obstaculização do processo, o que poderia levar a dificuldades e absurdos de ordem ainda maior. Não se crê, todavia, que o legislador tenha tido por expectativa criar facilidades para a aprovação de matérias de interesse exclusivo de uma minoria, mas antes, o de viabilizar a gestão dotando-a dos instrumentos para fazer frente às pressões oportunistas da oposição.

Contudo, dada a natureza dos homens, dominada pelas paixões, marcada pelos vícios, interesses egoístas, comportamentos insensatos, oportunistas e aguerridos, observada por tantos, a exemplo de Hobbes (1979) e Locke (1978), e em que pese Bobbio (2000a, p. 185), após a apresentação e a ampla discussão dos argumentos entre os que defendem o "governo dos homens ou o governo das leis", ter declarado que

[...] não tenho nenhuma hesitação em dizer que prefiro o governo das leis e não o governo dos homens. O governo das leis celebra hoje seu triunfo na democracia. E o que é a democracia se não um conjunto de regras (as chamadas regras do jogo) para a solução de conflitos sem derramamento de sangue? E em que consiste o bom governo democrático se não, acima de tudo, no rigoroso respeito a essas regras?;

Hoje o que se verifica é que mesmo a lei criada para a defesa contra a natureza humana, se presta, ela, também, como instrumento para revelar as manifestações humanas mais egoístas.

Giannetti (2007, p. 137) observa que "[...] a prosperidade material resulta da combinação adequada entre (a) regras do jogo e (b) qualidade dos jogadores", bem como adiante acrescenta: "A qualidade dos jogadores - as variações de motivação e conduta na ação individual - afeta a natureza das regras do jogo e exerce, juntamente com elas, um papel decisivo no desempenho da economia" (GIANETTI, 2007, p. 199). Em outras palavras, conforme a qualidade dos jogadores, a regras podem ter outros fins até mesmo estranhos aos que lhe foram causa; assim, em que pese o campo específico a que Gianetti se refere, o econômico, não há prejuízo na generelização do que afirma; de outro lado, os antecedentes autorizam a pensar que, se deixados ao sabor das circunstâncias, seja devido às ambiguidades ou às lacunas das leis, os jogadores serão tentados a construir pseudomaiorias para aprovar interesses que, de fato, são de uma minoria que, não raro, os quer transformar em direitos e privilégios contra o Estado e, por extensão, contra a sociedade, responsável pelo seu financiamento.

Na sequência, ao tempo em que são apresentadas outras características institucionais do ambiente político-legislativo brasileiro, procurar-se-á demonstrar que muitas iniciativas e decisões, embora propagadas como de interesse e aprovadas pela maioria podem, de fato, ou até mesmo de direito, estar encobrindo iniciativas que representam interesses minoritários.

\section{As distorções no sistema eleitoral frente ao ideal democrático}

É sabido que são dois os principais sistemas eleitorais, denominados por Nicolau (1999, p. 10) como macrofamílias de representação: "Os sistemas majoritários têm como propósito fundamental garantir a eleição do(s) candidato(s) com maior(es) contingente(s) de voto(s); os sistemas proporcionais tencionam distribuir os postos em disputa de maneira equânime à votação obtida pelos competidores". Ademais, são inúmeras as variantes, algumas caracterizando sistemas mistos.

No caso brasileiro, o primeiro dos sistemas é utilizado para a escolha entre os postulantes aos 
cargos do Poder Executivo, bem como aos de senador, enquanto que a representação proporcional é empregada para a escolha dos demais representantes parlamentares - deputados e vereadores - em todos os níveis de governo. Embora imbuídos do princípio democrático da maioria, na prática verificam-se distorções que também podem comprometer o ideal no que tange à efetiva representação da maioria, como a seguir será evidenciado.

\section{Situações nas quais a maioria no sistema majoritário corresponde à minoria}

Para um melhor entendimento, se faz necessário um breve esclarecimento e análise do tratamento conferido pela atual legislação aos votos brancos e nulos.

\section{O Tratamento aos Votos Brancos e Nulos}

O Artigo $2^{\circ}$ da Lei 9.504/97 (BRASIL, 1997) estabelece que "Será considerado eleito o candidato a Presidente ou a Governador que obtiver a maioria absoluta de votos, não computados os em branco e os nulos", e o seu $\S 1^{\circ}$ afirma que "Se nenhum candidato alcançar maioria absoluta na primeira votação, far-se-á nova eleição [...] concorrendo os dois candidatos mais votados, e considerando-se eleito o que obtiver a maioria dos votos válidos". A eleição para a escolha do titular para o Poder Executivo municipal é abordada no artigo $3^{\circ}$ que, no seu $\S 2^{\circ}$, abre uma consideração específica: "Nos Municípios com mais de duzentos mil eleitores, aplicar-se-ão as regras estabelecidas nos $\S \S 1^{\circ}$ a $3^{\circ}$ do artigo anterior".

Assim, para efeitos práticos, em primeiro lugar e de acordo com a legislação brasileira, os votos brancos e nulos são equivalentes, inválidos, e, por isso, excluídos da contagem para apurar o vencedor. No que tange ao que ora se debate, quais as implicações desta regra? À guisa de reflexão considere o caso a seguir, uma hipótese extrema mas que não pode ser desprezada. Exemplo: a) sistema majoritário; b) colégio eleitoral: 20 eleitores; c) 3 candidatos: A, B e C. Entre outras, tomese a matriz de possíveis resultados mostrada na Tabela 1.

TABELA 1- Peso relativo dos votos inválidos - casos hipotéticos

\begin{tabular}{|l|r|r|r|r|}
\hline $\begin{array}{c}\text { Distribuição } \\
\text { dos votos }\end{array}$ & \multicolumn{1}{c|}{ Hip. } & Hip. & Hip. & Hip. \\
III & IV \\
\hline Brancos/Nulos & 10 & 5 & 0 & 2 \\
\hline Candidato A & 3 & 10 & 15 & 10 \\
\hline Candidato B & 2 & 4 & 3 & 5 \\
\hline Candidato C & 5 & 1 & 2 & 3 \\
\hline
\end{tabular}

Conforme se verifica, a proximidade com o sentido democrático inserto em cada uma das hipóteses é bastante distinta, ainda que se diga, a título de justificativa, que os resultados são as expressões das vontades dos eleitores; assim, dependendo do número de votos brancos e nulos, é possível que o vencedor do pleito não reúna a aprovação e a preferência da maioria, mas sim, expresse a opinião da minoria em relação ao conjunto efetivo de eleitores, que é o sentido real da participação democrática.

Por oportuno, embora fuja ao escopo desta discussão, há que se refletir sobre a exclusão dos votos nulos e brancos, o que os iguala, quando, na verdade, são distintos e repletos de significados: 


\section{Ivan Antônio Pinheiro, Guilherme Moreira Conte, Luciano José Martins Vieira e Paulo Cesar Delayti Motta}

enquanto o voto em branco pode significar indiferença (com relação aos candidatos), apatia e desinteresse (ou desilusão com a prática política?), o voto nulo tem sido associado à manifestação de protesto, quer aos candidatos ou ao sistema político-eleitoral como um todo, mas também pode revelar erro de comunicação junto a determinados públicos, entre outras possíveis explicações.

No que concerne ao que ora se discute, importa relevar o fato de que a exclusão dos votos brancos e nulos equivale a situá-los no mesmo nível das abstenções, estas, sempre criticadas como sendo uma prática da não-cidadania, de fuga, de omissão frente aos temas de interesse e relevância para a comunidade. Pior, carrega um efeito perverso na medida em que, de regra, contribui para o resultado oposto ao pretendido pelo eleitor que, através do voto nulo ou branco firma o seu protesto. Sim, porque em um sistema eleitoral que admite a reeleição e o ato de protesto é dirigido contra o governo, ao votar em branco ou anular o seu voto, o eleitor (incauto) acaba facilitando (porque reduz o número de votos necessários à obtenção da maioria necessária) a reeleição do candidato situacionista, que é exatamente o oposto do que ele pretendia. Em outras palavras, não é dada ao eleitor a oportunidade de discordar das propostas de todos os candidatos (que na maioria das vezes são poucos, à exceção das capitais onde a disputa tende a ser mais acirrada) e tampouco lhe é dada a oportunidade de dizer "não, eu não aprovo esta gestão e tampouco vejo no candidato alternativo uma boa opção". Esse quadro é ainda mais grave quando se sabe, de acordo com Aydos (1995), que muitas eleições são plebiscitárias; assim, ao fim e ao cabo, ao votar em branco ou anular o seu voto o eleitor, eventualmente, referenda um sistema que, ainda que circunstancialmente, ele rejeite. Em aberto, a seguinte questão: a quem interessa esse modelo e conjunto de instituições?

Enfim, como qualquer manual de marketing chama a atenção, a "não-resposta" é uma das respostas mais relevantes em uma pesquisa (e o processo eleitoral é também uma pesquisa), não podendo ser excluída da análise e, muito menos, de ser considerada no que é de mais importante: o encaminhamento de propostas, a tomada de decisões, etc. A Hipótese. I, se por um lado se revela extremada, por outro, não é descabida, sobretudo se no cenário grassam denúncias de práticas ilícitas a exemplo do nepotismo, da improbidade administrativa, do abuso de poder, da corrupção, do peculato, entre outras manifestações que revelam desapreço à moral e ao compromisso com a res publica. É provável que esta realidade também esteja contribuindo para o efetivo e crescente distanciamento entre as iniciativas e as atitudes do agente (o representante político) e as expectativas do seu principal (o eleitor contribuinte), descompasso esse que, com frequência, tem sido constatado pelos institutos de pesquisa e amplamente noticiado pela mídia.

Em segundo lugar, a legislação ao restringir (provavelmente devido à relação custo/benefício) a exigência do segundo turno às localidades que contam com acima de 200 mil eleitores, criou, de pronto, algo exótico: a maioria regional. Efetivamente, enquanto nos municípios mais populosos acima de 200 mil eleitores - para ser eleito no primeiro turno é necessária a maioria absoluta, nos menores a maioria simples é suficiente para consagrar o eleito que, não é demais repetir, pode inclusive ser derrotado pelo número de votos brancos e nulos (significando apatia ou rejeição total da comunidade); mas, com um único voto (o seu), se hipoteticamente os demais anularem ou votarem em branco, ser eleito pela "maioria". Ridículo e esdrúxulo, sim! Mas isso é tanto legal quanto possível!

A opção pela maioria absoluta pretende conferir e aumentar a legitimidade do titular do Poder Executivo que, assim, se sentirá mais à vontade para conduzir a gestão, que a todos vincula, sobretudo, quando as iniciativas forem sobremodo impopulares, situação que se torna fragilizada no caso da maioria simples, sempre passível de questionamento, como ilustra Lemos (2004) na matéria em que destaca que nos 33 dentre os 496 municípios gaúchos que tiveram seus Prefeitos eleitos com menos de $50 \%$ do total de votos apurados, houve questionamento (em vão) no sentido de 
apontar a necessidade de um segundo turno.

Como derradeiro exemplo, tome-se o caso de um município que contou com três candidatos; um reuniu $34 \%$ dos votos e os outros dois, $33 \%$ cada um, sem que tenha havia votos inválidos. Note-se que mesmo tendo ocorrido $100 \%$ de participação, uma das dimensões da democracia e hipótese razoável em comunidades pequenas, a segunda dimensão, a da representação, estará seriamente comprometida em virtude de o critério utilizado ser o da maioria simples: pois se de um lado o vencedor poderá afirmar que reuniu a maioria dos votos $(34 \%)$, de outro, os oponentes poderão dizer o mesmo com base no fato de que ele foi rejeitado pela maioria (66\%). E aí, quem está certo? Do ponto de vista legal, não há questionamento, mas se considerado o princípio democrático e das consequências advindas, há que se refletir.

Portanto, conforme discutido, a expressão Estado Democrático e de Direito comporta matizes e nuances no que tange à participação e à representatividade dos que ocupam cargos no Poder Executivo e, na raiz, o conceito e a prática do que, afinal, se considera o que seja a maioria.

Em parte, as objeções aos diferentes conceitos de maioria e o impacto do tratamento conferido aos votos brancos e nulos, já observados no sistema de votação majoritária, se verificam, também, no caso do sistema proporcional, ou seja, mais do mesmo, embora este comporte nuances específicas conforme será visto a seguir.

\section{Situações nas quais a maioria no sistema proporcional corresponde à minoria}

O Art. $5^{\circ}$ da Lei $n^{\text {o. }}$ 9.504/97 (BRASIL, 1997) dispõe que: "Nas eleições proporcionais, contam-se como válidos apenas os votos dados a candidatos regularmente inscritos e às legendas partidárias".

$\mathrm{Na}$ eleição proporcional o voto é considerado do Partido, sendo o candidato, para este efeito, um mero agente divulgador da visão de mundo, dos princípios e das propostas do Partido pelo qual compete. Com isso, os votos nominalmente atribuídos aos candidatos se somam aos atribuídos à legenda para definir quantas cadeiras, das em disputa, serão atribuídas ao Partido tendo em vista o total de votos assim obtidos vis-à-vis o quociente eleitoral - número mínimo de votos necessário ao direito a um assento na Casa Legislativa. Esse sistema admite o voto em lista fechada, aberta ou híbrida.

No Brasil é adotado o sistema proporcional com lista aberta, o que implica, após a definição de quantas cadeiras o Partido tem direito, na escolha em ordem decrescente de votos, de tantos quantos forem os candidatos necessários para completar quota-parte de quociente eleitoral a que o Partido fez jus. Assim, no sistema proporcional, muitos se esforçam durante a campanha para que poucos cheguem ao topo e, se de um lado se verifica um esforço cooperativo para o Partido, de outro os candidatos são concorrentes entre si. À guisa de ilustração, nas eleições de 2010, apenas cerca de $7 \%$ dos candidatos eleitos o fizeram com votação própria, o que revela a sua dependência dos votos atribuídos à legenda, bem como o quanto são beneficiários dos votos atribuídos aos seus concorrentes de Partido.

Tais características, e é bom que se diga que não são do conhecimento nem mesmo do cidadãoeleitor mais instruído, somadas ao perfil modal do eleitor e a um hábito cultural (a motivação ao voto é de natureza e afinidade pessoal, ao invés de ideológica-programática), tem causado grandes distorções na representação democrática. A mais conhecida é o fato de que candidatos que recebem uma grande quantidade de votos, eventualmente não são eleitos porque o Partido não atingiu o quociente eleitoral, provocando, de certo modo, mais especificamente no eleitor incauto, uma surpresa, pois o candidato da maioria não consegue assento na Casa Legislativa. 


\section{Ivan Antônio Pinheiro, Guilherme Moreira Conte, Luciano José Martins Vieira e Paulo Cesar Delayti Motta}

Entre outros, foi o caso da ex-Deputada (RS) Luciana Genro que, no último pleito para a Câmara Federal, em 2010, apesar de ter recebido uma das maiores votações individuais (aprox. 130 mil votos), pelo fato de o Partido pelo qual concorreu - o PSOL - não ter atingido o quociente eleitoral, não teve direito a assento no Parlamento, enquanto outros, menos votados, foram eleitos. De outro lado, há o efeito dos "puxadores de votos": candidatos que por algum motivo, por vezes até mesmo excentricidades (o que faz alguns considerarem tais votos como sendo de protesto através de escárnio), reúnem um número expressivo de votos, aumentando a quota-parte a que tem direito o Partido pelo qual concorrem. No pleito de 2010 o caso mais famoso foi o do candidato e atual Deputado Federal Francisco Everardo O. Silva, mais conhecido como Tiririca, palhaço profissional. Outro caso nacionalmente notório é o do ex-Deputado Federal Enéas F. Carneiro.

Desse modo, embora pelo critério do número de eleitores (sem esquecer que o voto é obrigatório) o Brasil seja considerado uma das maiores democracias do mundo, nem sempre, devido às regras do jogo, o candidato da maioria (tendo como foco a pessoa física) é o eleito, pois a maioria, neste caso, corresponde à votação recebida pelo Partido. Vale observar que, no limite, no sistema proporcional um candidato pode ser eleito sem ter recebido um voto sequer! Sim, pois se de três candidatos, um deles é expressivo puxador de votos, levando o Partido a superar em três vezes o quociente eleitoral, os outros dois candidatos não precisam, a rigor, de nenhum voto para ser eleitos, beneficiados que serão pelos votos recebidos pelo primeiro. Nesse caso, se também é legal, pois como visto a legenda se sobrepõe ao candidato, é frustrante do ponto de vista do significado e da representação democrática, sobretudo quando se constata que o voto do eleitor brasileiro não traduz posicionamento ideológico-programático, mas antes uma identificação pessoal conforme anteriormente afirmado.

Assim, porque desconhece as nuances do funcionamento político-eleitoral-partidário, o eleitor acaba envolvido pela estratégia do Partido, habilmente administrada pelos profissionais de marketing e, ao fim e ao cabo, o seu voto, de regra em caráter pessoal, referenda uma nem sempre clara proposta partidária.

Por fim, entre as alternativas mitigadoras desse comportamento e suas consequências, sempre cogitadas, porém de difícil implementação porque contrárias aos interesses corporativos, podem ser alinhadas: (i) a adoção do voto distrital, que implica também na adoção do sistema majoritário para a escolha dos representes do povo; e, (ii) a implementação do sistema de lista fechada, o que deixaria mais explícito o fato de o voto pertencer ao Partido, desde que, para se obter os resultados esperados, se fizessem acompanhar de intensa campanha educacional e de esclarecimento, não episódicas, mas continuadas. A redução do número de Partidos, mediante a exigência de um número mínimo de votos (cláusula de barreira) também não deveria ser descartada porque menos ofensiva à democracia do que o sistema atual.

\section{As distorções ao princípio da maioria no seio do poder legislativo}

São três os casos a seguir analisados: a prática de logrolling (literalmente: rolagem do tronco) refere a alguém que recorre a um vizinho para ajudá-lo a rolar um tronco que, sozinho, jamais conseguiria -, a representação na Câmara Federal e, a aprovação em caráter terminativo.

\section{Logrolling}

Conforme Tullock (2005), logrolling significa "troca de votos". É um termo anglo-saxônico que designa "troca de favores" e, no contexto político deste artigo utilizado para definir as coalizões 
oportunistas, percebidas quando dois ou mais grupos buscam apoio (de votos) de outros grupos para os seus respectivos projetos, constituindo, assim, uma união, já que a aprovação seria impossível através dos votos isolados de cada um. Nas palavras desse autor, "Um membro do Parlamento ou do Congresso concordará em votar a favor de um projeto de lei em que outro parlamentar está interessado em troca do voto desse parlamentar em outra matéria. A troca de votos é um fenômeno muito comum em qualquer sistema político democrático". (TULLOCK, 2005, p. 41)

O logrolling é um comportamento recorrente em sessões do legislativo e funciona da seguinte forma: um parlamentar frequentemente vota a favor de um projeto de lei que, se não aprecia, também não se opõe, em troca do compromisso de reciprocidade com um colega em relação a um projeto do interesse do primeiro. Explícita (pública) ou implicitamente, se fosse o caso, dependendo da situação, a única penalização passível seria a desaprovação moral, pois a troca de votos não pode ser considerada crime, mas antes, parte do jogo político, portanto, não retira a validade da votação e tampouco inibe a prática, sobretudo se a votação for secreta.

Um dos casos mais evidentes de logrolling foi revelado por Pinheiro e Motta (2003a, 2003b, 2006), tendo como palco o Legislativo gaúcho, quando descrevem o processo das emancipações municipais ocorridas no Rio Grande do Sul em 2001. Os parlamentares representantes ou comprometidos com as áreas interessadas constituíam, naturalmente, a minoria; todavia, em havendo muitas áreas, mais precisamente 30, interessadas em obter a emancipação (para a qual necessitam a autorização do Poder Legislativo estadual), a troca de votos viabilizaria, como demonstrado, a aprovação de cada processo-projeto em curso no parlamento, tendo assim sido aprovados pela maioria. A troca de votos foi evidente, pois, após vários meses de tramitação, alguns há mais de dois anos, todos os projetos foram apreciados e votados no mesmo dia como se a emancipação de todos fosse do interesse da maioria dos gaúchos.

Mas se o logrolling é moralmente aceito, os efeitos para a sociedade podem ser perversos. Tome-se o seguinte exemplo hipotético: uma Casa Legislativa possui três representantes, cada um eleito por e representando um distrito eleitoral e, cada um, com rigorosamente o mesmo número de eleitores e cidadãos. Neste caso, cada parlamentar representa uma minoria da população regional - a totalização dos três distritos. Portanto, se cada um apresentar um projeto de interesse exclusivamente local, estará, perante o parlamento, defendendo o interesse de uma minoria - a do seu distrito eleitoral. Colocadas em votação, dificilmente as matérias lograriam aprovação porque não representam o interesse da região como um todo, exceto por uma linha compreensiva de raciocínio. Todavia, basta a troca de votos, o apoio recíproco, para estar assegurada a maioria (no mínimo de $2 / 3$, podendo ser a unanimidade) necessária à aprovação. Nos projetos que envolvem financiamento e recursos públicos a troca de votos tende a ser perversa, pois as iniciativas, embora de interesse localizado, e de uma minoria, são apresentadas à sociedade (financiadora), como tendo tido o apoio da maioria.

Como se percebe, a troca de votos é, também, um mecanismo de transferência de renda entre setores, regiões, e do setor público para o privado. Portanto, conforme também observado por Tullock (2005), há casos de logrolling que beneficiam as comunidades que, de outra forma, não seriam contempladas, por exemplo, com o financiamento, por toda a sociedade, de projetos de interesse exclusivamente local. Contudo, a troca de votos, combinada à regra da maioria simples (necessária à aprovação das Leis Ordinárias), favorece a manipulação e a captura, entre outros, do sistema de planejamento e orçamento público, por uma minoria que se apresenta como representante da maioria para legitimar as suas iniciativas e reivindicações.

\section{A Câmara Federal e a inconsistência da representação}

É lição histórica que as representações na Câmara Baixa devem guardar relação direta, isto é, 


\section{Ivan Antônio Pinheiro, Guilherme Moreira Conte, Luciano José Martins Vieira e Paulo Cesar Delayti Motta}

proporcionalidade com a população representada, assim, em princípio, estados mais populosos, maior a representação, se não preservando, aproximando-se, assim, de um dos cânones do regime republicano democrático: cada cabeça, um voto. Entretanto, diz o Art. 45 da Constituição Federal brasileira (BRASIL, 1988):

Art. 45. A Câmara dos Deputados compõe-se de representantes do povo, eleitos, pelo sistema proporcional, em cada Estado, em cada Território e no Distrito Federal.

$\S 1^{\circ} \mathrm{O}$ número total de Deputados, bem como a representação por Estado e pelo Distrito Federal, será estabelecido por lei complementar, proporcionalmente à população, procedendo-se aos ajustes necessários, no ano anterior às eleições, para que nenhuma daquelas unidades da Federação tenha menos de oito ou mais de setenta Deputados.

Deste dispositivo resulta uma das mais conhecidas, e sempre citadas, distorções ao princípio democrático: os estados mais populosos estão, relativamente, menos representados no parlamento federal, pois mesmo que aumentem a população, pelo crescimento vegetativo ou pelo movimento migratório (o que também corresponde à maior demanda por gastos públicos), não podem fazer corresponder, no parlamento, tal acréscimo, quebrando, assim, a propalada proporcionalidade democrática. $\mathrm{O}$ fato de o voto dos parlamentares ter o mesmo valor implica em dizer, grosso modo, que o voto de um representante dos estados do norte-nordeste vale mais do que o seu equivalente do sul-sudeste, pois os primeiros, em razão de o distrito eleitoral ser menor, necessitam de menos votos para ser eleitos. A Figura 1, a seguir, embora defasada, ainda é uma boa imagem para representar o que se ora se discute.

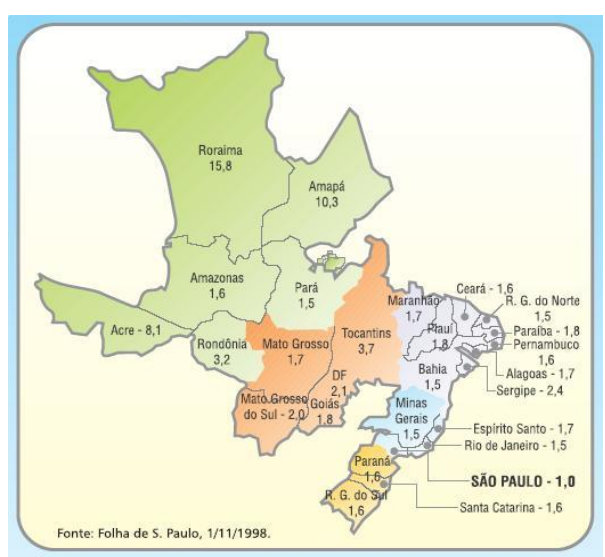

FIGURA 1: Como seria o mapa do Brasil se as áreas dos estados observassem a proporcionalidade da representação na Câmara Federal

Para ilustrar vamos considerar a seguinte situação: nas eleições de 1998 um candidato à deputado federal pelo estado de São Paulo, o mais populoso do Brasil, precisava de mais de 333 mil votos para ter direito a uma cadeira na Câmara nacional; de outro lado, um político concorrendo à representação do povo de Roraima precisava de em torno de 17 mil votos para alcançar o mesmo objetivo. Todavia, depois de eleitos, independentemente do número de votos recebidos ou do estado que representam, se grande ou pequeno, se desenvolvido ou não, esses deputados possuem os mesmos poderes, prerrogativas e atribuições. Assim, fica estabelecida uma grande iniquidade representativa, pois enquanto um representa 330 mil eleitores, o outro fala em nome de menos de cinco por cento deste valor.

Cabe lembrar que o agente público, em especial o político, não se expressa em seu nome, mas sim no daqueles que o elegeram para a função. Assim, ao igualar a possibilidade de voz de todos os deputados, o legislador constituinte colocou em xeque a regra da maioria - princípio ancilar da 
democracia. Sem dúvida que motivos houve, e quiçá ainda persistam, para que o legislador assim procedesse. Contudo, o fez à custa de um caro princípio democrático - "cada cabeça, um voto". Não cabe aqui tecer considerações quanto ao mérito e tampouco sobre os motivos que levaram a tal iniciativa, mas tão somente enumerar mais um exemplo que, ao lado de outros, faz com que a democracia contemporânea, e em especial no Brasil, esteja distante da noção que tanto domina o imaginário dos cidadãos quanto é explorada pela mídia.

Por fim, essa distorção não é novidade e, de quando em vez, como lembra Aydos (1995, p. 26), é trazida ao debate: "Pois, vencido o plebiscito, acomodaram-se também os presidencialistas no esquecimento das mudanças que deveriam aperfeiçoar a dinâmica do sistema de governo. Não se falou mais de proporcionalidade da representação entre os Estados na Câmara dos Deputados [...]”.

\section{A aprovação em caráter terminativo nas comissões do senado federal}

Apesar de o caso analisado ser o do Senado, situação semelhante é encontrada na Câmara Federal. Desconhece-se se nos estados membros ou em algum município tal procedimento também se verifica.

Sob o argumento de ser matéria de menor importância, de ser similar a outras tantas já debatidas na Casa, da necessidade de agilizar os trabalhos vis-à-vis projetos de maior relevância, enfim, razões insuspeitas, dotadas de lógica e bons propósitos, foi introduzida nos procedimentos do Senado a modalidade de aprovação das matérias em caráter terminativo quando da sua apreciação pelas Comissões. É significativo notar, no entanto, que os integrantes dessas Comissões não chegam a 30 senadores.

Por oportuno, cabe observar que a regra é a aprovação em caráter terminativo e, a menos que seja interposto recurso por pelo menos nove senadores, a matéria, para todos os efeitos, será considerada como se tivesse sido aprovada por toda a Casa. O Art. 235 do Regimento Interno do Senado (BRASIL, 1989) estabelece que:

Art. 235. A apresentação de proposição será feita:

I - perante comissão, quando se tratar de emenda apresentada de acordo com o disposto no art. 122;

II - perante a Mesa, no prazo de cinco dias úteis, quando se tratar de emenda a:

$[\ldots]$

c) projetos apreciados pelas comissões com poder terminativo, quando houver interposição de recurso;

$[\ldots]$.

Aprovados, os projetos têm, então, seu curso normal: à Câmara dos Deputados, à sanção presidencial, promulgados ou arquivados. Há exceções, isto é, matérias que não podem ser apreciadas em caráter terminativo, a exemplo das Emendas à Constituição. "Só em 2006 houve cerca de 500 aprovações em caráter terminativo no Senado, a maioria referentes a concessões de telecomunicações" (GOVERNET, 2011). Para que se tenha uma melhor ideia da natureza e amplitude do impacto das matérias aprovadas por 1/3 do Senado em nome de todos os Senadores, segue uma pequena amostra publicada pela Agência Senado (2011).

No final de dezembro de 2006, a Comissão de Serviços de Infra-estrutura (CI) aprovou em decisão terminativa a chamada Lei do Gás (PLS 226/05). O substitutivo aprovado estabelece um marco regulatório para o mercado de gás natural no Brasil, a exemplo do que já existe nos setores de energia elétrica, água e petróleo. Nas próximas semanas, a Mesa será comunicada da aprovação terminativa, quando terá início o prazo de cinco dias úteis para a interposição de recurso. Se nenhum for 


\title{
Ivan Antônio Pinheiro, Guilherme Moreira Conte, Luciano José Martins Vieira e Paulo Cesar Delayti Motta
}

\begin{abstract}
apresentado, a matéria segue diretamente para a Câmara dos Deputados.
$\mathrm{Na}$ mesma situação estão os projetos de lei do Senado 415/05, 403/03 e 173/01, entre outros. O primeiro estabelece normas gerais para a simplificação do procedimento de registro de empresários e pessoas jurídicas. O segundo prevê punições a quem praticar furtos de frequiências de telefone celular (clonagem) e de sinais de televisão por assinatura, com o objetivo de obter lucro. Já o PLS 173/01 dá maior proteção às vítimas e testemunhas de crimes como assassinato e roubo, que poderão optar por não depor na presença do acusado ou prestar depoimento com capuz ou usando microfone com modificador de voz.

Projetos aprovados terminativamente por comissões do Senado continuam tramitando na Câmara dos Deputados. O chamado Estatuto da Igualdade Racial (PLS 213/03) foi remetido à Câmara no final de novembro de 2005, depois de ter sido aprovado na Comissão de Constituição, Justiça e Cidadania (CCJ). O estatuto contém mecanismos para a promoção da igualdade racial, inclusive nos meios de comunicação. O PLS 63/06 inclui a ética e a cidadania no currículo da educação básica. Ainda em tramitação, ele foi aprovado na Comissão de Educação (CE) em agosto de 2006 e enviado à Câmara no mesmo mês.

Também ainda estão tramitando na Câmara o projeto que concede adicional de periculosidade aos carteiros (PLS 82/03); o que aprova a regulamentação das atividades dos grupos circenses brasileiros (397/03) e o projeto que prorroga até 2016 os incentivos previstos na chamada Lei do Audiovisual. Todos foram aprovados em decisão terminativa por comissões do Senado e remetidos à Câmara.
\end{abstract}

Por fim, ainda que na origem os fins que justificaram a iniciativa tenham sido meritórios, nada assegura que como tal permaneçam. Ao contrário, a flexibilidade interpretativa é a norma e não a exceção no ambiente político, como bem demonstra o fluxo (edição, admissibilidade, discussão, modificação e aprovação) das Medidas Provisórias.

Se as matérias aprovadas em caráter terminativo são de somenos importância, então que se altere a legislação para eliminar a sua apreciação por essa Casa, tendo-se o mesmo efeito, ou seja, a desobstrução da pauta para conferir celeridade à apreciação dos encaminhamentos de maior importância. É possível que semelhante tratamento possa resultar em descrédito do Senado, a exemplo da matéria sobre a Câmara, veiculada no Jornal Nacional (JORNAL NACIONAL, 2011), onde pode ser visto que apenas dois parlamentares, em sessão da Comissão de Constituição e Justiça, em menos de quatro minutos, aprovaram mais de 100 projetos.

\section{Outras situações nas quais a minoria usurpa o poder da maioria}

Sem a pretensão de exaurir o tema, outros três casos merecem a atenção antes do encaminhamento final: o caso das Medidas Provisórias, o das Mesas Diretoras, e o antigo processo de consulta no caso das emancipações municipais.

\section{As Medidas Provisórias}

Conforme visto na seção 3.1, as Medidas Provisórias (MP) constituem espécie do gênero processo legislativo. Previstas no Art. 62 da Constituição Federal (BRASIL, 1988), o Presidente da República, sob o pressuposto da urgência e da relevância, pode editar MP com o efeito imediato da força da lei sem a prévia apreciação do Poder Legislativo, devendo, contudo, de imediato submetêla ao Congresso Nacional que deverá constituir Comissão específica para analisar a admissibilidade e posterior conversão em lei. Trata-se, em última análise, de uma extensão do poder discricionário já previsto, entre outros, por Locke (1978), uma vez que o legislador não pode a priori prever e incorporar no texto da lei todos os aspectos da gestão e, tampouco, a dinâmica do processo legislativo encontra correspondência com a velocidade imposta aos atos de gestão, mormente em economias complexas.

Mas, se de um lado há pouca divergência quanto à necessidade e à importância deste instrumento 
ter previsão constitucional, de outro, o mesmo não pode ser dito no que tange à frequência com que o mesmo tem sido utilizado pelos governos, conforme foi discutido por Pinheiro, Vieira e Motta (2011). Ademais, é objeto de crítica o fato de que cabe a um pequeno grupo (minoria) decidir sobre a admissibilidade (quanto à urgência e à relevância) da iniciativa do Poder Executivo, sobretudo: (i) quando há exemplos, no passado, de que o próprio Poder Executivo já teria retirado de pauta MPs editadas e; (ii) a partir do momento que detém o controle da base governista no parlamento, a noção de urgência e relevância ganha contornos bastante elásticos.

Reafirmando o eixo deste ensaio, é mais um exemplo da supremacia da minoria, pois, admitida, dificilmente a MP, até em razão dos efeitos já produzidos, não será, com a aprovação do plenário que, seguindo as regras da maioria já vistas, convertida em lei ordinária.

\title{
O poder das Mesas Diretoras das casas legislativas
}

Embora de composição variável, em respeito à autonomia que identifica os estados membros em arranjo federado, as Mesas Diretoras das Casas Legislativas, em geral, são compostas por um Presidente, um ou dois Vice-Presidentes, Secretários e suplentes, talvez com alguma variação, mas não muita. Sem dúvida, um pequeno conjunto de parlamentares - a minoria da minoria - que, entretanto, possui um grande poder concentrado em suas mãos. Mas como se manifesta este poder? A título de exemplo, tome-se o que diz o Art. 48 do Regimento Interno do Senado Federal (BRASIL, 1987):

\begin{abstract}
Art. 48. Ao Presidente [do Senado, e da Mesa Diretora] compete:
$[\ldots]$;

VI - designar a Ordem do Dia das sessões deliberativas e retirar matéria da pauta para cumprimento de despacho, correção de erro ou omissão no avulso e para sanar falhas da instrução;
\end{abstract}

$[\ldots]$

Assim, à Mesa Diretora, em geral com a colaboração do Colégio de Líderes (outro conjunto reduzido), compete (dito de outra forma: tem o poder para) definir os assuntos que entrarão em pauta de discussão e votação no plenário da Casa. Então, diferentemente do princípio aplicado à gestão de estoques de uma organização, onde a regra do FIFO - First in First Out - não encontra restrições, a agenda parlamentar tem natureza diversa e, porque complexa e dinâmica, requer flexibilidade, daí não ser possível obedecer, rigorosamente, à ordem cronológica dos eventos e das iniciativas.

Avulta o poder conferido à Mesa Diretora quando se constata que a inclusão de determinadas matérias na agenda implica a exclusão de outras tantas, provavelmente em muito maior número. Isto, de certo modo, impede a apreciação destas por parte de representantes eleitos para tal, deixando, assim, de exprimir a vontade daqueles que representam e os elegeram, a saber, o povo. Sob o questionável, e por vezes casuístico argumento da falta de consenso político em torno do seu mérito, alguns assuntos deixam de ser pautados e é provável que muitos sejam deixados para as calendas gregas. Assim, a rigor, sobretudo nas maiores Casas, nada impede que a minoria exclua da apreciação da maioria os temas que não lhe são do interesse; todavia, a mídia noticia que, por exemplo, o Congresso, aludindo à Casa como um todo, à maioria dos seus integrantes decidiu não deliberar sobre tal ou qual assunto.

Apesar dos argumentos a favor dos poderes conferidos à Mesa, é inegável o enorme poder discricionário reunido por este pequeno grupo, quando não por acordo de lideranças, eleito 


\section{Ivan Antônio Pinheiro, Guilherme Moreira Conte, Luciano José Martins Vieira e Paulo Cesar Delayti Motta}

indiretamente, isto é, pelos seus pares.

\section{O caso das emancipações municipais}

O caso das emancipações, por já ter sido analisado em detalhes por Pinheiro e Motta (2003a, 2003b, 2006), merece tão somente uma breve menção. Ademais o problema à época apontado pelos autores, também um exemplo de minoria que, se não se sobrepõe, impede a manifestação da maioria, já foi corrigido da legislação. Os autores relatam que de acordo com a legislação à época do estudo, uma vez iniciado o processo de emancipação política, por um ou mais distritos descontentes com a administração central do município-mãe, em algum momento a proposta deveria ser submetida à consulta, na forma de plebiscito, à população de referência, isto é, aos habitantes das respectivas áreas. Portanto, cabia tão somente ao conjunto de eleitores, não raro uma minoria, a manifestação contrária ou a favor da iniciativa.

O flagrante contra o princípio democrático da maioria é constatado pela ausência da manifestação, também direta, por parte dos demais eleitores do município-mãe, das áreas não envolvidas no processo, por certo, a maioria. Assim, nos termos da lei, muitas municipalidades obtiveram a sua emancipação aprovada pela maioria, tendo sido registrado, no Rio Grande do Sul, assim como Brasil, uma profusão de novos municípios, a maioria sem recursos próprios e, por consequência, dependente das transferências constitucionais (o Fundo de Participação) e também das voluntárias, dos respectivos estados membros e da União.

Finalmente, os abusos foram de tal ordem que, por iniciativa do Poder Executivo federal, a legislação foi modificada, tendo-se aumentado as exigências que hoje incluem a consulta à toda a comunidade, como se verificou com a proposta de criação de dois novos estados como desdobramentos do estado do Pará: o de Tapajós e o de Carajás.

\section{Algumas considerações críticas}

É provável que todos os casos analisados: o da maioria simples para a aprovação das Leis Ordinárias; as consequências da regra da maioria simples combinada ao tratamento dos votos brancos e nulos no caso das eleições majoritárias; o desprezo da votação majoritária no caso do sistema proporcional; a troca de votos; a distorção representativa na Câmara Federal; a aprovação em caráter terminativo nas Comissões do Senado; o fluxo das Medidas Provisórias; e, finalmente, o poder das Mesas Diretoras e das Lideranças Partidárias, nas circunstâncias históricas da sua adoção como norma (exceto o caso do logrolling, por ser antes uma prática) tenham sido devida e justificadamente motivados. Assim, se de um lado cada qual confronta um dos cânones do sistema democrático, a saber, a participação majoritária nos processos decisórios, e por isso merecedor de crítica, de outro, atende a uma necessidade específica que justifica a sua existência, o que é meritório. Todavia, o acúmulo de exceções ao princípio democrático não deixa de ser preocupante, sobretudo quando a bandeira democrática, associada à ampla participação, é sempre içada para conferir legitimidade aos atos dos agentes públicos. Seria isto, então, uma manobra estratégica? Por oportuno, cabe observar que esta é uma das características da burocracia, onde cada ato e iniciativa, vistos isoladamente se configuram como racionais, mas quando agrupados, por vezes revelam irracionalidades.

No caso do processo legislativo, não bastasse o acúmulo de “exceções" para agilizar os procedimentos, preocupa, sobremodo, o uso combinado e cumulativo de alguns expedientes, a exemplo das aprovações em caráter terminativo mediante maioria simples, ainda que atendido o quórum mínimo regimental. Nesse caso, observa-se que o poder de um dos Poderes da República, quiçá o principal, porque origem dos demais está de fato e de direito, no Caso do Senado, não nas 
mãos de 81 Senadores, mas nas de não mais do que dez pessoas! No caso da Câmara, onde há 513 representantes, a situação é, relativamente, pior, pois o poder está mais concentrado. Não há que se perder de vista, também, que no curso da práxis legislativa é mais fácil convencer 10,15 ou 20 parlamentares a apoiar uma iniciativa, ou mesmo mudar de opinião, do que influenciar a maioria absoluta dos integrantes da Casa em apreço. Assim, e não obstante, quando é notícia que o Senado ou a Câmara aprovou uma medida, subliminarmente é veiculada, também, a mensagem de que, se não toda, a maioria absoluta da Casa tenha se manifestado pela aprovação, o que, agora se sabe, não é o que acontece.

Nota-se que os antigos, Platão (2000) e Aristóteles (2007), não estavam errados nas suas preocupações com a democracia, pois todas as iniciativas ora relatadas e contrárias à democracia foram decididas em ambiente democrático. Já os modernos, Locke (1978), Mill (2006), e mais recentemente, Bobbio (2000a), parece que estavam errados ao temer a ditadura da maioria, pois não é o que ora se verifica, pelo menos no Brasil, onde cada vez mais o poder tem sido concentrado nas mãos de grupos cada vez menores.

Por oportuno, não é demais lembrar que o parlamento, em que pese se afirmar que corresponde a uma amostra (um microcosmo) da sociedade, esta é, antes, uma figura de linguagem, pois a representação não guarda relação com o conceito de "amostra estatisticamente representativa" (ainda que estratificada); assim, por definição, os representantes são porta-vozes de grupos de interesses regionais, setoriais, de categorias profissionais, etc., em defesa de objetivos específicos e bem definidos. Nelson Jobim, por exemplo, citado por Bolzoni (2010)), declarou que

No Parlamento Nacional, nós temos lá o que? O Brasil dos professores, o Brasil dos policiais civis, o Brasil dos policiais militares, o Brasil dos advogados, o Brasil dos juízes, o Brasil dos promotores, o Brasil de Santa Maria, o Brasil das individualidades. E quem é que tem a obrigação de pensar o país? (...) Porque pensar o país não elege ninguém e quem pensar o país acaba não se elegendo.

A corroborar a manifestação do ex-Ministro da Justiça, da Defesa e ex-Presidente do Supremo Tribunal Federal, a matéria de Moura (2006), com o sugestivo título de O Deputado dos Camioneiros, publicada no diário Zero Hora $(\mathrm{ZH})$ de 27.10.2006, onde se lê: "Francisco Appio quer lutar por uma revisão das concessões rodoviárias. O preço do pedágio está muito alto". Na mesma linha segue a matéria também publicada na mesma edição de ZH (2006, s.p.): "Gilberto Capoani quer atrair investimentos ao Planalto Médio e Alto Uruguai - um político de status regional". Assim, mutatis mutandis, o voto no parlamento continua sendo em defesa das classes, não mais, como na França pré-revolucionária, reduzidas a três, mas longe, também, de se poder afirmar que os parlamentares representam o povo na sua totalidade, senão por outros motivos, pelo fato de haver uma impossibilidade prática: a heterogeneidade populacional, mesmo se pensada em estratos.

Se o sentido de isonomia não foi perdido, ele se encontra distante dos primeiros ideais vis-à-vis à prática democrática, esta mais próxima da eunomia que, entretanto, tem os parlamentares como novo conjunto de referência, um novo grupo de pares. Contudo, conforme visto, a realidade também se afasta da eunomia, pois cada vez mais prevalece a "representação dos representados", uma prática quase, se não já institucionalizada - uma nova categoria de análise e, por extensão, uma nova modalidade de democracia, pois com um nível adicional de representação, os primus inter pares. Há de se notar uma curiosa, se não paradoxal situação: enquanto o conjunto de representados cresce, o de representantes diminui!

Conforme visto, cabe ainda ressaltar que essa trajetória caminha na contramão da História. Assim, Rousseau (2000) também tinha razão quando apontou a impossibilidade de haver democracia efetiva na Era Moderna, pois se já é impossível ser representado pela maioria, com muito mais razão o é pela minoria, situação que se aproxima à que levou Kant (2010) a associar a democracia ao despotismo, embora este possivelmente viesse a se surpreender quanto ao sentido do "novo 


\section{Ivan Antônio Pinheiro, Guilherme Moreira Conte, Luciano José Martins Vieira e Paulo Cesar Delayti Motta}

despotismo". Por fim, é preciso cuidado para que o afastamento do ideal democrático não leve ao paradoxo do encontro de maiores similaridades entre a práxis de um Estado erigido sobre os princípios liberais e democráticos e o que Bobbio (2000a, p. 121-2) identifica no pensamento de Marx:

Para Marx, o Estado não é o reino da razão, mas o reino da força. Não é o reino do bem-comum, mas do interesse de uma parte. O Estado não tem por fim o bem-viver de todos, mas o bem-viver daqueles que detêm o poder, os quais, além do mais, têm sido até agora, na história da humanidade, uma minoria.

Seria essa concentração de poder uma imposição do mundo contemporâneo, complexo e a exigir decisões em tempos cada vez mais curtos? Alguns afirmam que sim. Contudo, de outro lado, esse novo ambiente também oferece soluções tecnológicas (as chamadas Novas Tecnologias de Comunicação e Informação) que possibilitariam ampliar a natureza e a diversidade das matérias, bem como a frequência com que poderiam ser submetidas à consulta da população. Um exemplo a ser considerado é dos Estados Unidos da América do Norte, onde diversos assuntos, além da escolha dos representantes, são submetidos à consulta do eleitorado. Ademais, no ambiente informatizado e das comunicações instantâneas não há maiores restrições e impedimentos à adoção do sistema Hare e, por que não, inicialmente, em caráter experimental, em um número reduzido de distritos eleitorais, como foi o teste da biometria?

A permanecer o quadro atual, onde a democracia, no Brasil, além de institucionalmente estar comprometida, assiste a desvios de conduta que resultam em assaltos constantes à res publica, surpreendentemente por aqueles que por ela deveriam zelar, é de se temer, como alertara Bobbio (2000a), pelo seu futuro, pois aos poucos vai se constituindo o ambiente, que a história ensina, ser favorável ao surgimento de aventureiros salvadores da pátria habilidosos na conquista dos corações e mentes dos exasperados com a degradação moral que assistem. Conforme visto, a passagem da democracia direta (participativa) à indireta (representacional) implicou sério comprometimento à democracia enquanto processo participativo com a contribuição da maioria. Portanto, agregar novos comprometimentos pode ser temerário.

No caso brasileiro, o quê fazer para aumentar o quantum democrático? Além das críticas já apontadas, que em si carregam sugestões implícitas, ainda que de certo modo fora do escopo deste ensaio (porque lhe falta a necessária sustentação teórica), mas que, por ser recorrente, tem sido abordado por vários autores, há que se destacar:

- o resgate ao princípio federativo que organiza o Estado brasileiro, há muito ferido pela concentração de poderes (leia-se, também, competências) na União; e,

- a redução no número de partidos, bem como a sua efetiva caracterização enquanto unidades ideológica e programaticamente distintas entre si. Wallerstein (2002), entre outros, a exemplo de Bobbio (2001), observa que não mais do que três grandes visões ideológicas orientam o mundo e constituem o lastro dos partidos políticos. Todavia, apoiadas no falso silogismo de que a efetiva democracia corresponde à opinião e à vontade de todos (200 milhões de cidadãos!) e que por isso seria qualitativamente melhor quanto maior fosse o número de representantes nas casas legislativas, várias iniciativas lograram sucesso e, atualmente, o Brasil já conta com quase 30 , tendentes a 50, partidos políticos. Nas palavras do anterior Presidente do Tribunal Superior Eleitoral, "estamos indo além do pluripartidarismo, estamos ingressando no hiperpartidarismo. É uma novidade que criamos no Brasil" (LEWANDOWSKI, 2011, p. 6). Que não sejam três ou quatro, talvez um pouco mais, mas tantos, s.m.j., servem a mal disfarçados interesses e tendem a confundir os eleitores, nada agregando à democracia. 
Enfim, apresentados os fatos que compõe a realidade, convida-se a comunidade acadêmica para refletir e discutir as suas implicações na cidadania no âmbito e no curso do Estado Democrático e de Direito.

\section{Referências}

AGÊNCIA SENADO. ESPECIAL: Decisões terminativas agilizam atividades do Senado. Disponível em: http://cnc.deolhonaweb.com.br/noticias/especial-decisoes-terminativas-agilizamatividades-do-senado. Acesso em: 21.09.2011.

ARISTÓTELES. Ética a Nicômaco. São Paulo: Martin Claret, 2007.

AYDOS, Eduardo Dutra. Democracia Plebiscitária: utopia e simulacro da reforma política no Brasil. Porto Alegre/Canoas: Ed. Universidade/UFRGS/Centro Educacional La Salle de Ensino Superior, 1995.

BLUCHE, Frédéric; RIALS, Stéphane; TULARD, Jean. A Revolução Francesa. Rio de Janeiro: Zahar, 1989.

BOBBIO, Norberto. Liberalismo e Democracia. São Paulo: Brasiliense, 1988.

O futuro da democracia. $10^{a}$ ed. São Paulo: Paz e Terra, 2000a.

$2000 \mathrm{~b}$.

A Teoria das Formas de Governo. 10 $10^{\mathrm{a}}$ ed. Brasília: Editora Universidade de Brasília,

Teoria Geral da Política - a filosofia política e as lições dos clássicos. Org. por Michelangelo Bovero. $4^{\mathrm{a}}$ Tiragem. Rio de Janeiro: Campus, 2000c.

Entre duas Repúblicas: as origens da democracia italiana. Brasília/São Paulo: Editora Universidade de Brasília/ Imprensa Oficial do Estado, 2001.

. A Era dos Direitos. Nova Edição. Rio de Janeiro: Elsevier, 2004.

BOLZONI, Fernando B. XXII Congresso Estadual de Servidores de Câmaras Municipais do Rio Grande do Sul. Palestra: Sistemas Eleitorais - 23.09.2010. Rio Grande do Sul, Assembléia Legislativa, Escola do Legislativo Dep. Romildo Bolzan. Disponível em: http://docs.google.com/viewer?a=v\&q=cache:vEfqBZRBUs0J:ascamrs.com.br/Palestras/Bolzoni/Si stemas\%2520Eleitorais-

ASCAM.ppt+No+Parlamento+Nacional,+n\%C3\%B3s+temos+1\%C3\%A1+o+que\%3F+O+Brasil+d os+professores\&hl=pt-BR\&gl=br\&pid=bl\&srcid=ADGEESiLJP1A7S0zaJ9YkPdBIDKmZ2y-

1UBkBrRYT32UopZg7tN9nD6L4EufhnptZbgqiWgXO9we14l-zrveiyJQlm8K-bF11Oa5JdO11d_a2WVov57Samx0o5ZWD5Fkb1UkqSFYRhZ\&sig=AHIEtbQvsdj24IGD_hc9CiUVmZD Ec4oLnA. Acesso em: 10.10.2011

BRASIL. Constituição Federal e Emendas. Disponível em: http://www.senado.gov.br/legislacao/const/con1988/CON1988_13.07.2010/index.shtm. Acesso: 21.09.2011.

Lei Federal $\mathbf{n}^{\mathbf{0}}$ 9.504, de 30 de setembro de 1997. Estabelece normas para as eleições. Disponível em: http://www.planalto.gov.br/ccivil_03/Leis/L9504.htm. Acesso: 21.09.2011 . 
Regimento Interno do Senado. Texto editado em conformidade com a Resolução no 18, de 1989, consolidado com as alterações decorrentes de emendas à Constituição, leis e resoluções posteriores, até 2010. Disponível em: http://www.senado.gov.br/legislacao/regsf/. Acesso: 21.09.2011.

BROSSARD [de Souza Pinto], Paulo. Ser ou não ser. Zero Hora, Porto Alegre, 08.03.2004, p. 19. Coluna: Opinião.

. Lamentável. Zero Hora, Porto Alegre, 23.05.2005, p. 15. Coluna: Opinião.

CAMPANELLA, Tommaso. A Cidade do Sol. São Paulo: Martin Claret, 2004.

CHURCHILL, Winston Disponível em: http://pensador.uol.com.br/frases_de_winston_churchill/2/. Acesso em: 27.09.2011

GIANNETTI, Eduardo. Vícios privados, benefícios públicos? - a ética na riqueza das nações. São Paulo: Cia. das Letras, 2007.

GOVERNET. Decisões terminativas agilizam atividades do Senado. Disponível em: http://www.governet.com.br/noticia.php?cod=868. Acesso em: 21.09.2011

HOBBES, Thomas. Leviatã. São Paulo: Abril Cultural, 1979.

KANT, I. À Paz Perpétua. Porto Alegre: L\&PM Pocket Plus, 2010.

JORNAL

NACIONAL.

Disponível

em:

http://www.youtube.com/watch?v=dlaw1XI5zPE\&feature=related. Acesso em: 26.09.2011.

LEMOS, I. Eleitos por minoria geram debate sobre segundo turno. Zero Hora, p. 13, 14.10.2004.

LEWANDOWSKI, Ricardo. Proliferação Partidária - reforma afunda e país ganha $29^{\mathrm{a}}$ sigla. Zero Hora, p. 6, 06.10.2011.

LOCKE, John. Segundo Tratado Sobre o Governo. São Paulo: Abril Cultural, 1978.

MILL, J. S. O Governo Representativo. São Paulo: Escala, 2006.

MORUS, Thomas. A Utopia. São Paulo: Escala, s.d.

MOURA, Heron. O Deputado dos Caminhoneiros. Zero Hora, Porto Alegre, 27.10.2006, p. 19. Coluna: Opinião.

NAY, Olivier. História das idéias políticas. Petrópolis, RJ: Vozes, 2007.

NICOLAU, Jairo Marconi. Sistemas Eleitorais. Rio de Janeiro: Fundação Getúlio Vargas, 1999.

OSTERMANN, Nilse W.; KUNZE, Iole C. Às Armas Cidadãos - a França revolucionária (17891799). São Paulo: Atual, 1995.

PINHEIRO, Ivan Antônio; MOTTA, Paulo Cesar Delayti. Significado e importância das emancipações: uma polêmica ainda não resolvida no Rio Grande do Sul. Revista Brasileira de Administração Pública. Rio de Janeiro, Brasil, v. 37, n. 4, p. 713-739, 2003 a. 
Emancipações no Rio Grande do Sul: racionalidade ou inconsequência nos processos de municipalização. Revista Brasileira de Administração Pública. Rio de Janeiro, Brasil, v. 37, n. 4, p. $741-775,2003 b$.

As Últimas Emancipações Municipais no Rio Grande do Sul. Revista de Administração Municipal. Rio de Janeiro, v. 51, n. 258, p. 56-68, 2006.

PINHEIRO, Ivan Antônio; VIEIRA, Luciano José Martins; MOTTA, Paulo Cesar Delayti. Mandando Montesquieu às favas: o caso do não cumprimento dos preceitos constitucionais de independência dos três poderes da república. Revista Brasileira de Administração Pública. Rio de Janeiro, Brasil, v. 45, n. 6, 2011.

PLATÃO. A República. São Paulo: Nova Cultural, 2000.

PRADO, Ney. Razões das Virtudes e Vícios da Constituição de 1988 - subsídios à revisão constitucional. São Paulo: IL/Inconfidentes, 1994.

ROUSSEAU, Jean-Jacques. Do Contrato Social. São Paulo: Nova Cultural, 2000. [v. I e II].

SANTI, Marcos Evandro Cardoso. Criação de Comissões Parlamentares de Inquérito: tensão entre o direito constitucional de minorias e os interesses políticos da maioria. Porto Alegre: Sergio Antonio Fabris Ed., 2007.

TULLOCK, Gordon. A Teoria da Escolha Pública. IN: TULLOCK, Gordon; SELDON, Arthur; BRADY, Gordon. Falhas de Governo: uma introdução à teoria da escolha pública. Rio de Janeiro: Instituto Liberal, 2005.

WALlERSTEIN, I. Após o Liberalismo - em busca da reconstrução do mundo. Petrópolis, RJ: Vozes, 2002. 